\title{
Comparison of Four Methods for Demonstrating Glucose Breakdown by Bacteria
}

\author{
By J. J.S. SNELL AND S. P. LAPAGE \\ National Collection of Type Cultures, \\ Central Public Health Laboratory, Colindale Avenue, London, N.W.9 \\ (Accepted for publication 20 July $197 \mathrm{I}$ ) \\ SUMMARY
}

Four methods for demonstrating the breakdown of glucose by bacteria have been compared, three of which depended on showing the production of acid from glucose and the fourth on detecting the removal of glucose from the medium. The four methods varied in sensitivity with different groups of bacteria and possible reasons for this are discussed in terms of interaction between glucose and protein metabolism.

\section{INTRODUCTION}

The ability of many bacteria to metabolize carbohydrates has long been used in classification and identification. This property is usually demonstrated by acid production from a carbohydrate incorporated in a nutrient medium, often a peptone water 'sugar' medium (PWS), in which the source of nitrogen is provided by peptone. This medium is useful for detecting acid production by bacteria which metabolize carbohydrates by fermentation because much acid is produced. However, bacteria which metabolize glucose oxidatively (non-fermenting bacteria) may produce less acidity (Hugh \& Leifson, 1953), and alkali produced by the bacteria from the peptone may neutralize any acid produced. Hugh \& Leifson (1953) developed $\mathrm{O} / \mathrm{F}$ medium in which a low concentration of peptone overcame these difficulties, and this medium has been widely used in studies of non-fermenting bacteria. Park ( 1967 ) modified the $\mathrm{O} / \mathrm{F}$ medium and developed a method in which the removal of glucose from a low peptone medium (modified Hugh \& Leifson medium - MHL) was demonstrated enzymically. Park found that some non-fermenting bacteria removed glucose from the medium but showed little or no acid production in the $\mathrm{O} / \mathrm{F}$ medium. Smith, Gordon \& Clark (1952) used a medium with ammonium sulphate as a nitrogen source to demonstrate acid production from carbohydrates by members of the genus Bacillus. This medium has also been used for non-fermenting bacteria (Lapage, Hill \& Reeve, I968).

In the present study a number of strains was tested for their ability to attack glucose using PWS medium, the O/F medium of Hugh \& Leifson (1953), Park's (1967) MHL medium, and ammonium salt sugar medium (ASS) (Smith, Gordon \& Clark, I952).

\section{METHODS}

Bacteria. A total of I8I strains, mostly non-fermenting bacteria, was used, comprising strains from the National Collection of Type Cultures (NCTC) and also more recently isolated strains. The groups used are listed in Table $\mathrm{I}$.

Peptone water sugar (PWS). Peptone, Io g.; NaCl, 5 g.; Andrade's indicator, $10 \mathrm{ml}$; glucose, $20 \mathrm{ml}$. of a $50 \%$ (w/v) Seitz filtered solution; distilled water, I 1 . The solids were 
dissolved in the water by heating, the $\mathrm{pH}$ was adjusted to $7 \cdot 4$ and the indicator added. After sterilizing the medium at $108^{\circ}$ for $30 \mathrm{~min}$. the sterile glucose solution was added and the medium distributed into sterile $150 \times 15.5 \mathrm{~mm}$. test tubes which were then steamed for $30 \mathrm{~min}$.

O/F medium (Hugh \& Leifson, 1953). Peptone, 2 g.; $\mathrm{NaCl}, 5 \mathrm{~g}$; $\mathrm{K}_{2} \mathrm{HPO}_{4}, 0.3 \mathrm{~g}$; agar, $3 \mathrm{~g}$; ; bromothymol blue, $\mathrm{I} 5 \mathrm{ml}$. of a $0.2 \%$ (w/v) aqueous solution; glucose, $20 \mathrm{ml}$. of a $50 \%$ (w/v) Seitz filtered solution; distilled water, I 1.

The solids were dissolved in the water by heating, the $\mathrm{pH}$ was adjusted to $7 \cdot 4$ and after filtration the indicator was added and the medium sterilized at $\mathrm{I} I 5^{\circ}$ for $\mathrm{I} 5 \mathrm{~min}$. After cooling to $50^{\circ}$ the sterile glucose solution was added and the medium distributed aseptically into equal numbers of two sizes of sterile tubes, I50 $\times 15.5 \mathrm{~mm}$. and $\mathrm{I} 25 \times \mathrm{I} 2.5 \mathrm{~mm}$., and allowed to set.

Ammonium salt sugar (ASS) (Smith, Gordon \& Clark, I952). $\left(\mathrm{NH}_{4}\right)_{2} \mathrm{HPO}_{4}$, I g.; $\mathrm{KCl}$, 0.2 g.; $\mathrm{MgSO}_{4} .7 \mathrm{H}_{2} \mathrm{O}$, $0.2 \mathrm{~g}$.; Yeastrel, $0.2 \mathrm{~g}$; agar, $12 \mathrm{~g}$.; bromocresol purple, $4 \mathrm{ml}$. of a $\mathrm{I} \%(\mathrm{w} / \mathrm{v})$ aqueous solution; glucose, $20 \mathrm{ml}$. of a $50 \%(\mathrm{w} / \mathrm{v})$ Seitz filtered solution; distilled water, I 1 . The solids were dissolved in the water by heating, the $\mathrm{pH}$ was adjusted to 7.0 and the indicator added. The medium was sterilized at $115^{\circ}$ for $15 \mathrm{~min}$. and after cooling to $50^{\circ}$ the sterile glucose solution was added. The medium was distributed aseptically into ' $R$ epli' dishes (square plastic dishes divided into 25 separate compartments, described by Sneath \& Stevens, 1967, and manufactured by Dyos Plastics Ltd, Surbiton, Surrey).

Modified Hugh and Leifson medium (MHL)(Park, I 967). Peptone, 2 g.; $\mathrm{NaCl}_{9} 5 \mathrm{~g}$.; $\mathrm{K}_{2} \mathrm{HPO}_{4}$, $0.3 \mathrm{~g}$.; glucose, I ml. of a $50 \%$ (w/v) Seitz filtered solution; distilled water, I l. The solids were dissolved in the water by heating, the $\mathrm{pH}$ adjusted to $7 \cdot 2$ and the medium sterilized by heating at $115^{\circ}$ for $15 \mathrm{~min}$. The sterile glucose solution was added to the cooled medium which was distributed aseptically into sterile $150 \times 15.5 \mathrm{~mm}$. test tubes.

Inoculation and reading of results. The media were inoculated with a straight wire from overnight cultures of the bacteria. Incubation was at $37^{\circ}$ except for strains of Pseudomonas fluorescens and Chromobacterium lividum which were incubated at $22^{\circ}$. The MHL medium was incubated with the test tubes tilted to ensure a large surface area of culture medium. With $\mathrm{O} / \mathrm{F}$ medium both a narrow and a wide tube were inoculated with each strain. The wider tubes were incubated aerobically and the narrow tubes were sealed with vaseline to produce anaerobic conditions. Results were read at I, 3, 5, 7 and 10 days, acid production being noted with the PWS and ASS media, acid or alkali production with the $\mathrm{O} / \mathrm{F}$ medium in both open and sealed tubes, and removal of glucose from the MHL medium by placing a drop of the medium on to a 'Clinistix' reagent strip (Miles Laboratories, Stoke Poges, Buckinghamshire). The 'Clinistix' strip develops a blue colour with glucose, hence removal of glucose from the medium was shown by the absence of this reaction.

Strains which showed differences in the results between the four methods were retested in all four media at least once.

\section{RESULTS}

The reactions of different groups of bacteria grown in the four media, are shown in Table I. In Table 2 the results for the $\mathrm{O} / \mathrm{F}$ medium have been scored only as either attack on glucose $(+)$ or no attack on glucose $(-)$ and the distinction between oxidation and fermentation, as well as alkali production, have been ignored. By this simplification the results shown in Table I fall into seven combinations of test results. These results show that the PWS medium is much less sensitive than the other three media and, although the ASS, 
MHL and O/F media showed similar totals of positive results, they differed from each other in their sensitivity to specific groups of bacteria.

Table I. Distribution of reaction patterns amongst several groups of bacteria

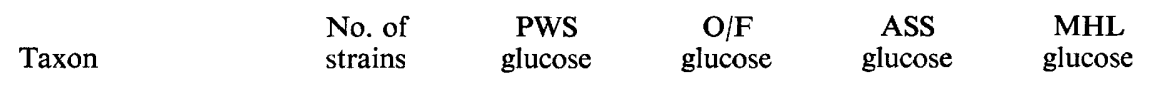

\begin{tabular}{|c|c|c|c|c|c|}
\hline Acinetobacter anitratus & $2 I$ & + & ox & + & + \\
\hline A. lwoffii & 16 & - & $-/$ alk & d & - \\
\hline Alcaligenes odorans & 4 & - & alk & - & - \\
\hline Alcaligenes spp. & 4 & - & alk & - & - \\
\hline Bordetella bronchiseptica & 14 & - & alk & - & - \\
\hline B. parapertussis & 3 & - & alk & - & - \\
\hline Chromobacterium lividum & 8 & - & ox & + & + \\
\hline C. violaceum & I4 & $\mathrm{d}$ & $\mathrm{f}$ & + & + \\
\hline \multicolumn{6}{|l|}{ Flavobacterium } \\
\hline meningosepticum & IO & - & ox & d & + \\
\hline Flavobacterium $\mathrm{sp}$. & I & + & ox & + & + \\
\hline Loefflerella mallei & 8 & d & ox & + & + \\
\hline Moraxella kingii & I & + & $\mathrm{f}$ & ng & + \\
\hline Moraxella spp. & 14 & - & - /alk & $-/ \mathrm{ng}$ & $-/ \mathrm{ng}$ \\
\hline Neisseria spp. & 12 & d & alk/ox/f/- & $-/ \mathrm{ng}$ & d \\
\hline Pseudomonas aeruginosa & 13 & - & ox & + & + \\
\hline$P$. alcaligenes & 5 & - & alk & - & - \\
\hline P. cepacia & I & + & ox & + & + \\
\hline P. fluorescens & 4 & $\mathrm{~d}$ & ox & + & + \\
\hline P. maltophilia & 3 & - & alk & - & + \\
\hline P. pseudoalcaligenes & 5 & - & alk & - & - \\
\hline$P$. pseudomallei & II & $\mathrm{d}$ & ox & + & + \\
\hline$P$. putida & 5 & $\mathrm{~d}$ & ox & + & + \\
\hline Pseudomonas spp. & $\begin{array}{l}3 \\
4\end{array}$ & - & ox/alk & $\mathrm{d}$ & $\mathrm{d}$ \\
\hline
\end{tabular}

+ , Acid produced in PWS and ASS media, and removal of glucose from the MHL medium; ox, oxidative result; - , no acid produced in PWS, O/F and ASS media, and no removal of glucose from the MHL medium; alk, alkaline; d, different strains gave different results; $f$, fermentative result; ng, no growth.

\section{Table 2. Observed combinations of results}

$\begin{array}{ccccc}\begin{array}{c}\text { No of } \\ \text { strains }\end{array} & \begin{array}{c}\text { PWS } \\ \text { glucose }\end{array} & \begin{array}{c}\text { O/F } \\ \text { glucose }\end{array} & \begin{array}{c}\text { ASS } \\ \text { glucose }\end{array} & \begin{array}{c}\text { MHL } \\ \text { glucose }\end{array} \\ 53 & + & + & + & + \\ 44 & - & + & + & + \\ 63 & - & - & - & - \\ \text { II } & - & - & + & - \\ 3 & + & + & - & + \\ 4 & - & + & - & + \\ 3 & - & - & - & + \\ \begin{array}{c}\text { Total no. of } \\ \text { strains positive }\end{array} \\ \text { +, Attack on glucose; -, no attack on glucose. }\end{array}$

\section{DISCUSSION}

The various combinations of results are discussed below, and both neutralization of acid by alkali produced from peptone (Hugh \& Leifson, 1953; Park, 1967) and preferential metabolism of peptone over glucose (Hamilton \& Dawes, 1959; Board \& Holding, 1960) appear to have played a part.

$P W S-, O / F+, A S S+, M H L+$. This combination suggests that the relatively high concentration of organic nitrogen present in the PWS interferes either with acid production 
due to repression of glycolysis, or with the demonstration of acid production due to alkali formation.

$P W S-, O / F-, A S S-, M H L+$. Only the three strains of Pseudomonas maltophilia gave this combination of results confirming the finding of Park (1967) that strains of P. maltophilia removed glucose from MHL medium but failed to produce acid in $\mathrm{O} / \mathrm{F}$ medium. Superficially, the results suggest that glucose is broken down without the production of acid, as not enough alkali would be produced from the traces of protein in the ASS medium to mask acid production, although enough might be produced in the $\mathrm{O} / \mathrm{F}$ medium to do so. This latter is confirmed by the fact that a strong alkaline reaction was given in the $\mathrm{O} / \mathrm{F}$ medium without glucose, and, in the medium with glucose, slight alkali production was indicated in the first few days of incubation but later disappeared. However, acid production in the ASS medium can readily be shown when methionine which is required absolutely for the growth of $P$. maltophilia (Iizuka \& Komagata, 1964), is added to the medium. Without methionine, strains of $P$. maltophilia grew poorly and probably too little to produce acid. Titration of uninoculated ASS and $\mathrm{O} / \mathrm{F}$ media with $\mathrm{N} / \mathrm{I} 00$ hydrochloric acid showed that the ASS medium required twice as much acid as the $\mathrm{O} / \mathrm{F}$ medium to effect a colour change. Hence the production of acid in the methionine-supplemented ASS medium but not in the $\mathrm{O} / \mathrm{F}$ medium was not due to any greater buffering capacity of the $\mathrm{O} / \mathrm{F}$ medium or a lesser sensitivity of its indicator.

$P W S-, O / F-, A S S+, M H L-$. These results were given by I I of the I 6 strains of Acinetobacter lwoffii probably due to preferential utilization of the peptone over the glucose in the PWS, $\mathrm{O} / \mathrm{F}$ and MHL media. They cannot be explained by masking of acid production (by alkali in the peptone-containing media) as glucose was not removed from the MHL medium.

$P W S d, O / F+, A S S-, M H L+$. These results were given by four strains of Neisseria, two of Flavobacterium meningosepticum and the single strain of Moraxella kingii. The negative results in the ASS medium were due to the paucity, or absence, of growth on this medium of those strains which had been previously shown (Snell, 1970) to have complex nutritional requirements.

The results obtained with the bacterial strains used in this study indicate that, although the $\mathrm{O} / \mathrm{F}$, ASS and MHL media are considerably more sensitive than PWS medium, no single medium is sufficient in all cases to demonstrate attack on glucose by the 'non-fermenting' bacteria. Although the distinction between a positive and a negative result for glucose breakdown in a given medium may be a useful diagnostic feature, no great taxonomic weight can be placed on such a distinction as a negative result is not necessarily evidence of the lack of the enzymes concerned with glucose breakdown; it may be the result of using a medium unsuitable for demonstrating this property.

These results show that ASS medium, originally designed for use with the genus Bacillus, is useful for the 'non-fermenting' bacteria, and this medium has been successfully used for carbohydrate studies on these bacteria over a period of years in the NCTC.

\section{REFERENCES}

BoARd, R. G. \& Holding, A. J. (1960). The utilization of glucose by aerobic Gram-negative bacteria. Journal of Applied Bacteriology 23, xi.

Hamilton, W. A. \& Dawes, E. A. (I959). A diauxic effect with Pseudomonas aeruginosa. Biochemical Journal $\mathbf{7 1}, 25 \mathrm{P}$.

Hugh, R. \& Leifson, E. (I953). The taxonomic significance of fermentative versus oxidative metabolism of carbohydrates by various Gram-negative bacteria. Journal of Bacteriology 66, 24-26. 
IzZUKA, H. \& Komagata, K. (1964). Microbiological studies on petroleum and natural gas. Journal of General and Applied Microbiology, Tokyo ro, 207-221.

LAPAGE, S. P., HiLL, L. R. \& REEve, J. D. (1968). Pseudomonas stutzeri in pathological material. Journal of Medical Microbiology I, 195-202.

PARK, R. W. A. (1967). A comparison of two methods for detecting attack on glucose by pseudomonads and achromobacters. Journal of General Microbiology 46, 355-360.

Smith, N. R., Gordon, R. E. \& Clark, F. E. (1952). Aerobic Spore-Forming Bacteria. United States Department of Agriculture Monograph no. 18, p. 35.

SNeATH, P. H. A. \& STEVENS, M. (1967). A divided petri dish for use with multipoint inoculators. Journal of Applied Bacteriology 30, 495-497.

SNeLl, J. J. S. (1970). Development of Tests for Biochemically Inactive Bacteria. Thesis, Fellowship of the Institute of Medical Laboratory Technology. 